\title{
Clonal proliferation of HTLV-1-infected cells is associated with spontaneous malignant tumor formation in mice
}

\author{
MASAKAZU TANAKA ${ }^{1,2,3}$, TAKAYUKI NITTA ${ }^{1,2}$, TOSHINORI YOSHIDA $^{4}$, TOMOKO KONISHI ${ }^{1,3}$, \\ YUSUKE KAWAZU ${ }^{1,3}$, JUN-ICHI FUJISAWA ${ }^{3}$ and MASANAO MIWA ${ }^{1,2}$ \\ ${ }^{1}$ Graduate School of Bioscience, Nagahama Institute of Bio-Science and Technology, Nagahama, \\ Shiga 526-0829; ${ }^{2}$ Institute of Basic Medical Sciences, University of Tsukuba, Tsukuba 305-8575; \\ ${ }^{3}$ Department of Microbiology, Kansai Medical University, Moriguchi, Osaka 570-8506; \\ ${ }^{4}$ Toxicology Division, Institute of EnvironmentalToxicology, Ibaraki 303-0043, Japan
}

Received May 21, 2009; Accepted June 3, 2009

DOI: 10.3892/ijo_00000382

\begin{abstract}
Adult T-cell leukemia/lymphoma (ATL) is characterized by monoclonal proliferation of tumor cells that harbor integrated human T-cell leukemia virus type-1 (HTLV-1). These malignant cells accumulate in various organs including the liver, spleen and skin in addition to blood and lymph nodes. Although there have been several reports of animal models of HTLV-1 infection in which proviral distribution has been examined, clonal expansion of the experimentally infected host cells has not been extensively analyzed. Here we provide experimental evidence that clonal proliferation of the infected host cells occurs in the spleen for more than one year. During a 15 month period of persistent infection, two out of ten mice developed spontaneous tumors. Although the tumors were not ATL-like, cells exhibiting mono- or oligoclonal proliferation and having the same site of HTLV-1 integration were identified in tumor tissues as well as in the spleen. Quantitative analysis of the cells belonging to each cell clone suggested that these proliferating cell clones were associated with the tumors and that spontaneous tumor tissues might provide a suitable microenvironment for proliferation and accumulation of infected cell clones at the late stage of infection.
\end{abstract}

\section{Introduction}

The most common human tumor viruses include human T-cell leukemia viruses (HTLVs), Epstein-Barr virus, Kaposi's sarcoma-associated herpesvirus, papillomaviruses and hepatitis B viruses. Understanding tumor viruses is important

Correspondence to: Dr Masanao Miwa, Graduate School of Bioscience, Nagahama Institute of Bio-Science and Technology, Nagahama, Shiga 526-0829, Japan

E-mail: m_miwa@nagahama-i-bio.ac.jp

Key words: human T-cell leukemia virus type 1, clonal proliferation, mouse model, linker mediated PCR not only because they cause human disease, but also because they serve as models for cellular and molecular studies of cell transformation. HTLV-1 was the first human oncogenic retrovirus to be isolated and characterized $(1,2)$. Leukemic cells from patients with ATL exhibit monoclonal integration of HTLV-1 proviral DNA, providing direct evidence for the involvement of the virus in the development of ATL $(3,4)$. However, retroviral infection may not always result in ATL because the incidence of ATL among HTLV-1 carriers is relatively low (5). After infection with HTLV-1, some of the infected cells exhibit clonal proliferation, albeit slowly, to achieve a carrier condition. Additional genetic changes in these clonally proliferating cells provide them with the selective advantage of growth, which eventually leads to leukemia/lymphoma (6). However, the pathophysiological mechanisms underlying these events are not well understood, making it difficult to analyze the pathogenesis of HTLV-1associated diseases and their prevention. Therefore the natural course, from the infection with HTLV-1 to the development of ATL, is still unclear. Suitable animal models are needed to elucidate the pathophysiology of HTLV-1 carriers.

To examine the pathology of HTLV-1 carriers, small animal models of HTLV-1 infection can be utilized. Mice are preferred over other animal models because extensive genetic information is available. In addition, we have demonstrated the efficient HTLV-1 infection of mice (7-10).

The aim of the present study was to investigate the association of HTLV-1 infection with clonal proliferation of HTLV-1-infected cell populations accumulating in the secondary lymphoid organs, especially in the spleen, and to determine whether HTLV-1 is detectable in spontaneous tumors from infected mice. At 15-18 months post-infection, spontaneous tumors were observed in four (mice 1,2,7 and 8) of ten infected mice. Three (mice 1, 2 and 7) of the four mice bearing spontaneous tumors had HTLV-1 provirus in the spleen. Furthermore, we found that two (mice 1 and 7) of the three infected mice acquired clonal proliferation of HTLV-1infected cells in the spleen during the observation period. Subsequently, we identified clonal proliferation of HTLV-1infected cell populations in tumor tissues of mice 1 and 7 . 


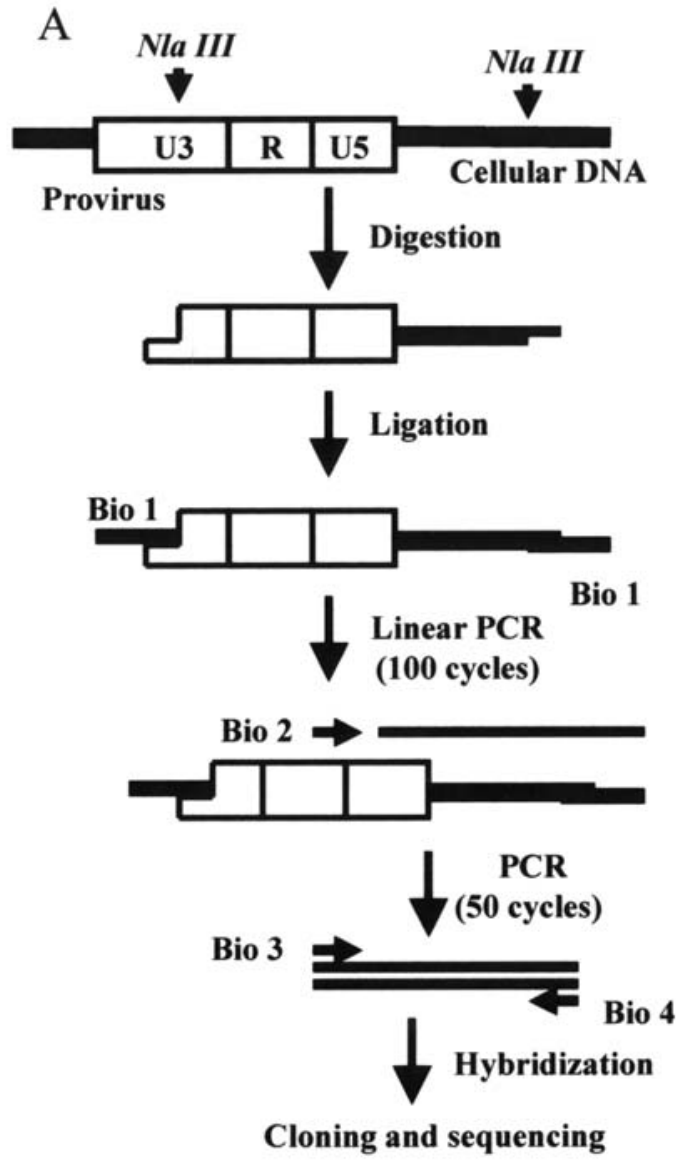

B

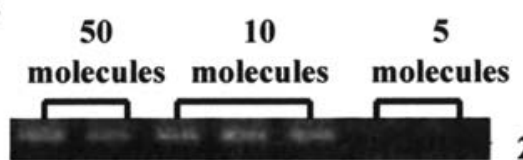

225 bp

Figure 1. (A) Schematic diagram of linker-mediated PCR amplification of HTLV-1 proviral integration sites. (B) DNA from ATL-1K cells, containing a single copy of HTLV-1 provirus per cell, was used to determine the sensitivity of the LM-PCR method. Genomic DNA amounts representative of 50,10 or 5 ATL-1K cells was subjected to LM-PCR amplification in duplicate or triplicate reactions using the primers indicated in panel (A). Amplification products were analyzed using agarose gel electrophoresis followed by ethidium bromide staining. No detectable amplification products were observed below 10 molecules of input provirus.

These findings indicate that clonal non-malignant proliferation of HTLV-1-infected cells readily occurs in HTLV-1 carriers. In addition, the condition of carrier states might enhance the spontaneous tumor cell growth.

\section{Materials and methods}

Cells and animals. MT-2 cells, an HTLV-1-infected human T-cell line (11) and ATL-1K cells, an HTLV-1-infected human $\mathrm{T}$-cell line containing a single copy of provirus per cell (12), were cultured in RPMI-1640 medium supplemented with $10 \%$ fetal calf serum. Pregnant $\mathrm{C} 3 \mathrm{H} / \mathrm{HeJ}$ (13) mice were purchased from CLEA, Inc., Tokyo, Japan. The offspring were each injected intraperitoneally with $2.5 \times 10^{6}$ MT- 2 cells within $24 \mathrm{~h}$ after birth and again at one week of age.
Quantification of HTLV-1 proviral load. The quantitative PCR conditions were as described previously (10). Briefly, the number of tax (viral gene) and mouse c-myc molecules (cellular gene as control) were quantified using real-time PCR and HTLV-1 proviral load per $10^{5}$ mouse cells was calculated as follows: (Number of tax molecules/number of mouse c-myc molecules/2) $\times 10^{5}$.

Amplification of proviral integration sites by linker mediated-PCR (LM-PCR). Amplification of the HTLV-1 provirus integration sites was performed using LM-PCR according to Cavrois et al (14) with slight modification (7). Genomic DNA $(5 \mu \mathrm{g})$ was digested with 15 units of Nla III (NEB, Inc., Beverly, MA, USA) for $6 \mathrm{~h}$ at $37^{\circ} \mathrm{C}$. Digested DNA was extracted by phenol-chloroform mixture and precipitated with ethanol and ligated with 100 pmol Bio-1 primer (5'-TCATGATCAATGGGACGATCACATG-3') using 2.8 Weiss units of T4 DNA ligase (Takara Biochemical, Tokyo, Japan) in a $40 \mu \mathrm{l}$ reaction for 4 or $16 \mathrm{~h}$ at $15^{\circ} \mathrm{C}$. Oneeighth of the ligated DNA was amplified by PCR in a $50 \mu 1$ reaction containing $10 \mathrm{mM}$ Tris- $\mathrm{HCl}(\mathrm{pH} 8.3), 50 \mathrm{mM} \mathrm{KCl}$, $2.5 \mathrm{mM} \mathrm{MgCl}_{2}, 80 \mathrm{pmol}$ of Bio-2 forward primer corresponding to the HTLV-1 3'LTR [5'-CTGTTCTGCG CCGTTACAGATCGA-3' (nt 8899-8922)], $200 \mu \mathrm{M}$ dNTPs and 1.25 units of AmpliTaq Gold. Thermal cycling was performed using a Robocycler (Stratagene, Inc., La Jolla, CA, USA) at $95^{\circ} \mathrm{C}$ for 9 min followed by 99 cycles at $95^{\circ} \mathrm{C}$ for $30 \mathrm{sec}, 61^{\circ} \mathrm{C}$ for $30 \mathrm{sec}$, and $72^{\circ} \mathrm{C}$ for $1 \mathrm{~min}$, followed by a final elongation step at $72^{\circ} \mathrm{C}$ for $7 \mathrm{~min}$. After diluting this linear PCR reaction products by 300 -fold by water, a portion $(0.5 \mu \mathrm{l})$ was mixed with a $25 \mu \mathrm{l}$ solution containing $10 \mathrm{mM}$ Tris- $\mathrm{HCl}$ (pH 8.3), $50 \mathrm{mM} \mathrm{KCl}, 2.0 \mathrm{mM} \mathrm{MgCl} 2,200 \mu \mathrm{M}$ dNTPs, 12.5 pmol each Bio-3 forward primer [5'-CTTT TCATTCACGACTGACTGACTGCCG-3' (nt 8939-8962)] and Bio-4 reverse primer (5'-TCATGATCAATGGGAC GATCA-3') and 0.25 units of Taq polymerase (Wako Chemicals, Osaka, Japan). PCR amplification was then performed at $95^{\circ} \mathrm{C}$ for $5 \mathrm{~min}$, followed by 50 cycles at $95^{\circ} \mathrm{C}$ for $30 \mathrm{sec}, 61^{\circ} \mathrm{C}$ for $30 \mathrm{sec}$, and $72^{\circ} \mathrm{C}$ for $1 \mathrm{~min}$, followed by a final elongation step at $72^{\circ} \mathrm{C}$ for $7 \mathrm{~min}$. For amplification of the integration sites, the primers were: Bio-1 (linker) and Bio-4, which is identical to Bio-1 except that it lacks four 3 '-terminal nucleotides. Bio-2 and Bio-3 anneal to the indicated locations in the 3 'LTR of HTLV-1 provirus. Amplification products were analyzed using agarose gel electrophoresis followed by ethidium bromide staining.

Cloning and sequencing. LM-PCR products containing DNA fragments flanking the 3'LTR of HTLV-1 provirus were subcloned into the pPCRII vector using the TA cloning kit (Invitrogen, Inc., San Diego, CA). Positive clones were identified by hybridization with the Bio-5 probe: 5'-TGG CTCGGAGCCAGCGACAGCCCAT-3' (nt 8996-9020). The final PCR product $(10 \mu 1)$ was subjected to $2 \%$ agarose gel electrophoresis. DNA fragments were transferred under alkaline condition onto a nylon membrane and hybridized with a ${ }^{32} \mathrm{P}-$ labelled LTR specific Bio-5 probe for $8 \mathrm{~h}$ at $42^{\circ} \mathrm{C}$. Membranes were washed three times for $10 \mathrm{~min}$ in $300 \mathrm{mM}$ $\mathrm{NaCl}$ and $30 \mathrm{mM}$ sodium citrate containing $0.1 \%$ SDS at $61^{\circ} \mathrm{C}$. The filter was then washed 3 times for $15 \mathrm{~min}$ at $57^{\circ} \mathrm{C}$ 
Table I. Proviral loads and clonal cell population in the spleen.

\begin{tabular}{|c|c|c|c|c|c|}
\hline $\begin{array}{l}\text { Week } \\
\text { P.I. }\end{array}$ & $\begin{array}{l}\text { Mouse } \\
\text { I.D. }\end{array}$ & $\begin{array}{c}\text { Proviral loads } 1 \text { ) } \\
\text { (molecules } / 10^{5} \text { cells) }\end{array}$ & $\begin{array}{l}\text { Clone } \\
\text { I.D. }\end{array}$ & $\begin{array}{l}\text { Clonal population (2) } \\
\text { (molecules } / 10^{5} \text { cells) }\end{array}$ & $\begin{array}{l}\text { Clonal occupancy } \\
(\text { (2)/(1) } \times 100)(\%)^{\mathrm{a}}\end{array}$ \\
\hline 15 & 1 & 277.6 & $1 \mathrm{C}$ & 160 & 57.6 \\
\hline \multirow[t]{15}{*}{18} & 2 & 204.9 & $2 \mathrm{C}$ & 40 & 19.5 \\
\hline & 3 & 171.8 & - & - & - \\
\hline & 4 & 284.8 & - & - & - \\
\hline & 5 & 37.8 & - & - & - \\
\hline & 6 & 61.3 & $6 \mathrm{C} 1$ & 10 & 16.3 \\
\hline & & & $6 \mathrm{C} 2$ & 10 & 16.3 \\
\hline & & & $6 \mathrm{C} 3$ & 20 & 32.7 \\
\hline & 7 & 133.2 & $7 \mathrm{C} 1$ & 80 & 60.1 \\
\hline & & & $7 \mathrm{C} 2$ & 10 & 7.5 \\
\hline & & & $7 \mathrm{C} 3$ & 10 & 7.5 \\
\hline & & & 7C4 & 10 & 7.5 \\
\hline & & & $7 C 5$ & 20 & 15.0 \\
\hline & 8 & $<10$ & - & - & - \\
\hline & 9 & 30.5 & - & - & - \\
\hline & 10 & 99.5 & - & - & - \\
\hline
\end{tabular}

${ }^{a}$ Number of cell clones with clonally integrated HTLV-1 provirus per number of total cells with provirus. P.I., post infection.

in $30 \mathrm{mM} \mathrm{NaCl}$ and $3 \mathrm{mM}$ sodium citrate $(0.2 \mathrm{X} \mathrm{SSC})$ containing $0.1 \%$ SDS. Positive clones were verified by automated sequencing (ABI377 autosequencer, PerkinElmer).

Quantification of HTLV-1 proviral copy numbers of HTLV-1integrated cell clones in the spleen. For each spleen cell clone, the HTLV-1 proviral copy number was estimated by PCR amplification of genomic DNA using Bio-2 as the forward primer and an oligonucleotide corresponding to the appropriate genomic sequence flanking the provirus integration site as the reverse primer (underlined sequences, Table II). The copy number was calculated by fold of dilution of genomic DNA to be detected by Southern blot analysis after amplification by PCR. PCR amplification conditions were essentially as described (6), except the amount of the template DNA was $0.5 \mu \mathrm{g}$ in $25 \mu 1$ reactions.

Histological examination. The spleen and tumor of mice were fixed in neutral formalin solution and embedded in paraffin. The paraffin sections of $4 \mu \mathrm{m}$ thickness were stained with hematoxylin and eosin. Peripheral blood smears from each animal were prepared on glass slides and stained with Wright Stain solution. Paraffin sections and smears were examined microscopically.

\section{Results}

Infection of mouse cells with HTLV-1. To analyze the process of clonal growth of HTLV-1-infected cells, C3H/HeJ mice were each injected intraperitoneally with $2.5 \times 10^{6} \mathrm{MT}-2$ cells, an HTLV-1-infected human T-cell line (7-9), within $24 \mathrm{~h}$ after birth and again at one week of age. However, the injected MT2 donor cells must be excluded from analysis of clonal expansion. We therefore determined the site of HTLV-1 integration in MT-2 donor cells and used this sequence to screen HTLV-1-infected mice surviving MT-2 donor cells (11). The analysis indicated that MT-2 cells, injected at neonatal period, were efficiently rejected from the spleen of mice within 2 weeks after infection. PCR analysis of DNA isolated from infected mouse spleens revealed that all HTLV-1-positive amplification products contained flanking sequences derived from the mouse genome and not from the MT-2 cell genome (data not shown). This was confirmed by PCR amplification of the identified flanking sequences from normal mouse DNA but not from MT-2 cell DNA $(8,9)$.

Determination of HTLV-1-integrated cell clones and proviral loads. Next we determined HTLV-1-containing cell clones in spleen samples using LM-PCR (Fig. 1A). Using ATL-1K cells as a control, the threshold of HTLV-1 copy number detection using the LM-PCR method was determined to be $>10$ HTLV-1 proviral molecules per $10^{5}$ cells. Therefore we estimated that one confirmed clone represented a unit consisting of 10 or more spleen cells with the same HTLV-1 proviral integration site per $10^{5}$ cells in our assay conditions.

Quantification of the proviral loads containing HTLV-1 proviral tax sequence in the mouse spleens was performed using real-time PCR. HTLV-1 provirus was detected in all mice except one (mouse 8; Table I). Excluding mouse 8, the range of proviral loads in the spleens were 30.5-284.8 molecules per $10^{5}$ cells. To check whether there was clonal proliferation of the infected cells, we estimated the cell numbers belonging to each clone by semiquantitative PCR 
Table II. Flanking sequences of HTLV-1 integration sites in the spleen.

\begin{tabular}{|c|c|c|c|}
\hline Month & Clone & Cellular flanking sequences & Size (bp) \\
\hline 15 & $1 \mathrm{C}$ & GATGCCTACAGGTTGAGCTGAAGAGGGACAGCCATG & 36 \\
\hline \multirow[t]{23}{*}{18} & $2 \mathrm{C}$ & ATCATCTCCAGACATTTTACATAGCATAACACTTTGATGTGTGA & 57 \\
\hline & & GACAGTAGCCATG & \\
\hline & $6 \mathrm{C} 1$ & GGGTTTCATCCCCTTTCCTGAACCTTAAATCAGTTACTGATTGG & 189 \\
\hline & & TTATCCCCACAATCTTTGTACCAACTTTACCCTAGCATATCTTA & \\
\hline & & CAGGCAGTGTTTGCATTTCTCCTTTGAGTCTGTGCAAAGTACTT & \\
\hline & & TGTACCAGAGACACTGGAGCATG & \\
\hline & $6 \mathrm{C} 2$ & AGACTTGGTGTAAATGTAAACACAGCTTGAAATTTGAAATTTCAT & 82 \\
\hline & & СTTATTCCTAGGGGGACCTAGTTTATTCTGGTGCATG & \\
\hline & $6 \mathrm{C} 3$ & $\begin{array}{l}\text { TTTTCCAAAAAAAAAAAAAAGAAGAAATCAGTCCGGGCAGTGGTG } \\
\text { GCACATG }\end{array}$ & 52 \\
\hline & 7C1 & GCAAGCCAGTAAGTACCATCCCTCCATG & 28 \\
\hline & $7 \mathrm{C} 2$ & $\begin{array}{l}\text { GAGTCTCACTATGAAATTATGGCTGGCCTGGAAGTCATAAGTAGCC } \\
\text { TATGGAGTGCTGGGATATAAGTCATG }\end{array}$ & 72 \\
\hline & $7 \mathrm{C} 3$ & TCTATTTGCCTTGAAGTCAGGATAACATCAGTGTTAAAAAGAGGTGA & 153 \\
\hline & & GTGCTCCCAGTGAGTGTCCTAACATAGCTTGCCAGGAAGCCCCAGC & \\
\hline & & $\begin{array}{l}\text { AAACAATCCCCACCCCCACCCCAAAGACCTCACCTGCAATTGCTTA } \\
\text { CAGCAGACAGCATG }\end{array}$ & \\
\hline & $7 \mathrm{C} 4$ & GATACTCTGTTAACAGCTGTCTGGAATGATTTCCTACAGGAAGGTAC & 281 \\
\hline & & CTCTGAAATGACTCAAGGAAGAAGAATAAAGATTATTTCTAGACTAG & \\
\hline & & AATGAATATGCTTGCAAGAGAGAAGATTCTGAGAGAGGTAATCAGAA & \\
\hline & & TAAAGATGCTTAGAGACATAGAAATGTTTATAGTCCAGAGCTCATATC & \\
\hline & & TCCTGGCAAAAGGTAGACAGTGCATCATTTCCAGGGAAGATGAGGTT & \\
\hline & & GGGAGACAGACAGAGGCTAGATAATGCCCAGCTCTGTATGACATG & \\
\hline & $7 \mathrm{C} 5$ & CTTCTCAATAGTCACAAATGATATAAAATATCTTGGCGTGACTCTAAC & 137 \\
\hline & & TAAGGAAGTGAAAGATCTGTATGATAAAAACTTCAAATCTCTGAAGAA & \\
\hline & & AAAATTAAGGAAGATCTCAGAAGATGGAAAGATCTCCCATG & \\
\hline
\end{tabular}

The reverse primers used for quantification of the cell clones are shown underlined.

amplification using serial dilutions of genomic DNA from spleens; Bio-2 was the forward primer, and the reverse primers were derived from portions of the murine genomic sequence flanking the provirus integration site (underlined sequences, Table II) $(8,9)$. These results indicated that each spleen sample contained 10-160 clonal cells with the same provirus integration site per $10^{5}$ splenocytes. Furthermore, the clonal occupancy, which was defined as the percentage of the number of cells belonging to cell clones in total number of HTLV-1-infected cells, was 7.5-60.1\% in splenocytes (Table I).

Proviral integration sites. It is well established that clonal growth of MuLV-infected cells results from insertional mutagenesis through integration in or around various growthrelated genes $(15,16)$. A similar mechanism was recently proposed for ATL $(17,18)$. Therefore we analyzed the HTLV-1 integration sites in the clonal cell populations from spleens of infected $\mathrm{C} 3 \mathrm{H} / \mathrm{HeJ}$ mice (Table II). All sequences flanking the provirus insertion sites were either repetitive sequences or uncharacterized sequences. Further characterization will therefore be required to determine the effect of proviral insertion in clonal growth, including identification of genome sequences that are not annotated at present.

HTLV-1 infection-associated tumor formation and clonal cell proliferation. We found three tumor-bearing mice out of 10 mice following HTLV-1 infection (mice 1, 2 and 7). We therefore examined whether these tumors contained clonally proliferated HTLV-1-infected cells. We found that two mice (mouse 1 and 7) acquired clonal proliferation of HTLV-1infected cells in the spleen and tumor. Interestingly, LMPCR amplification of spleen and tumor DNA from mouse 1 resulted in products of similar size (Fig. 2A). Cloning and sequencing of these flanking sequences, revealed that the spleen and tumor DNA represented one identical clone (clone 1C). Mouse 1 developed a tumor in a lymph node at 15 months. The lymph node histopathology indicated proliferation of myeloid leukemia cells mixed with some histolytic cells (Fig. 2B). Mouse 1 also displayed spleno- 
Mouse 1

A
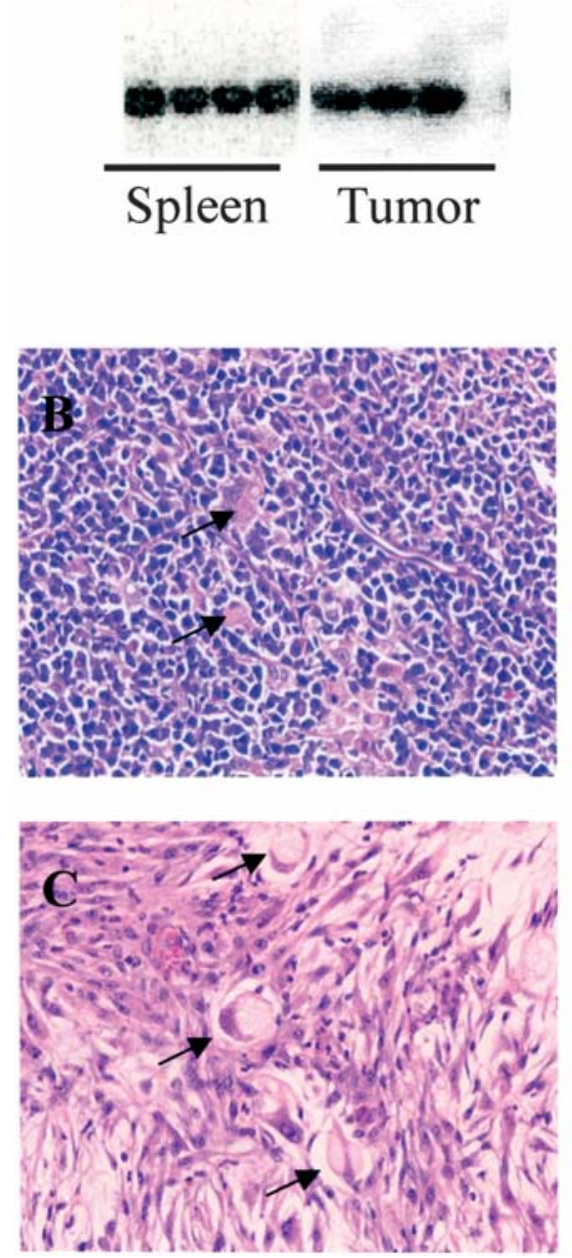

Mouse 7

D

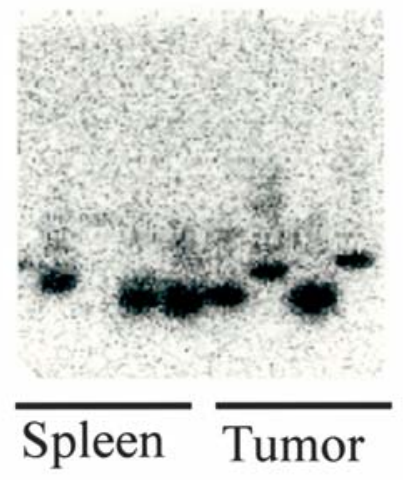

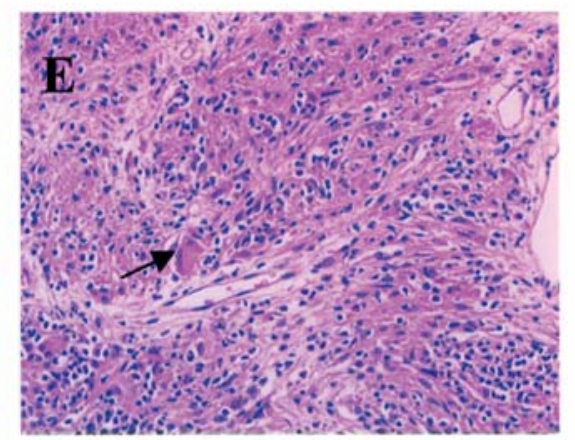

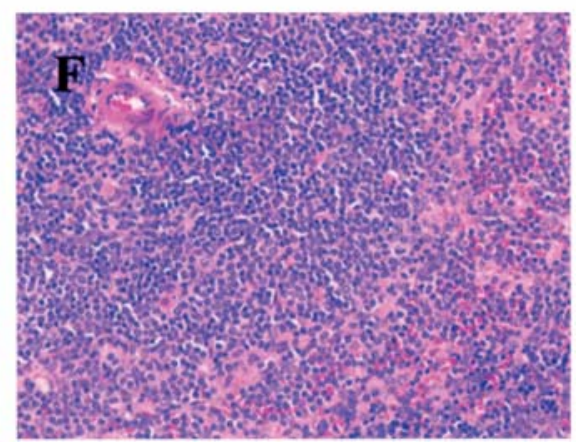

Figure 2. LM-PCR and histopathological analyses on tumors and spleens of HTLV-1-infected mice. Mouse 1 (A) LM-PCR analysis of cell clones in the spleen and tumors obtained from mouse 1 after 15 months of persistent infection. LM-PCR products from quadruplicate assays are shown. (B) Image (magnification, x210) of a lymph node section stained with hematoxylin and eosin. Myelogenic leukemia in the lymph node demonstrating proliferation of myeloid cells mixed with some histolytic cells is shown (arrows). (C) Image (magnification, x210) of a spleen tissue section stained with hematoxylin and eosin. Malignant histiocytomas in the spleen demonstrating tumor cells with pale eosinophilic cytoplasm and multinucleated giant cells are shown (arrows). Mouse 7 (D) LM-PCR analysis of cell clones in the spleen and tumors obtained from mouse 7 after 18 months of persistent infection. LM-PCR products from quadruplicate assays are shown. (E) Image (magnification, x210) of a tumor tissue section stained with hematoxylin and eosin. A liposarcoma in the subcutaneous tumor tissue consisting of many spindle cells and some fat-producing cells is indicated (arrow). (F) Image (magnification, $\mathrm{x} 210$ ) of the section of the spleen tissue showing white pulps and red pulp with no histopathological changes. Stained with hematoxylin and eosin.

megaly with malignant histiocytoma in the spleen (Fig. 2C). In mouse 7, several clones of HTLV-1-infected cells were proliferating in the spleen and in the tumor (LM-PCR analysis; Fig. 2D). Mouse 7 developed a subcutaneous liposarcoma at 18 months (Fig. 2E) but had no histological changes in the spleen (Fig. 2F).

The proviral loads in the spleen of mice 1 and 7 were 277.6 and 133.2 molecules per $10^{5}$ cells, respectively. Furthermore, the proviral loads in the tumors of mice 1 and 7 were 1477.3 and 720.8 molecules per $10^{5}$ cells, respectively. We next analyzed the clonal proliferation and its association with tumorigenesis by quantifying oligo- or monoclonally proliferating cells with integrated HTLV-1 provirus. The number of cells belonging to each cell clone was determined by PCR amplification using Bio- 2 as the forward primer and portions of cellular DNA flanking sequences as reverse primers (underlined sequences, Fig. 2). The limit of detection of the PCR signal was assumed to correspond to at least one molecule of the provirus. Using this technique, the abundance of cells belonging to each cell clone having the same integration site was compared between the spleen and the tumors from the same mouse (Fig. 2, Table III). The number of cells (corresponding to the number of provirus molecules) belonging to clone $1 \mathrm{C}$ was estimated to be 160 
Table III. Clonal occupancy in the reservoir and in the tumor of tumor-bearing mice.

\begin{tabular}{|c|c|c|c|c|c|c|}
\hline $\begin{array}{l}\text { Week } \\
\text { P.I. }\end{array}$ & $\begin{array}{l}\text { Mouse } \\
\text { I.D. }\end{array}$ & Organ & $\begin{array}{c}\text { Proviral loads } 1 \text { ) } \\
\text { (molecules } / 10^{5} \text { cells) }\end{array}$ & $\begin{array}{l}\text { Clone } \\
\text { I.D. }\end{array}$ & $\begin{array}{l}\text { Clonal population } 2 \\
\text { (molecules } / 10^{5} \text { cells) }\end{array}$ & $\begin{array}{l}\text { Clonal occupancy } \\
(\text { (2)/(1) } 100)(\%)^{\mathrm{a}}\end{array}$ \\
\hline \multirow[t]{2}{*}{15} & 1 & Spleen & 277.6 & $1 \mathrm{C}$ & 160 & 57.6 \\
\hline & & Tumor & 1477.3 & $1 \mathrm{C}$ & 640 & 43.3 \\
\hline \multirow[t]{10}{*}{18} & 7 & Spleen & 133.2 & $7 \mathrm{C} 1$ & 80 & 60.0 \\
\hline & & & & $7 \mathrm{C} 2$ & 10 & 7.5 \\
\hline & & & & $7 \mathrm{C} 3$ & 10 & 7.5 \\
\hline & & & & $7 \mathrm{C} 4$ & 10 & 7.5 \\
\hline & & & & $7 \mathrm{C} 5$ & 20 & 15.0 \\
\hline & & Tumor & 720.8 & $7 \mathrm{C} 1$ & 160 & 22.2 \\
\hline & & & & $7 \mathrm{C} 2$ & 160 & 22.2 \\
\hline & & & & $7 \mathrm{C} 3$ & 320 & 44.4 \\
\hline & & & & $7 \mathrm{C} 4$ & 20 & 2.8 \\
\hline & & & & $7 \mathrm{C} 5$ & 20 & 2.8 \\
\hline
\end{tabular}

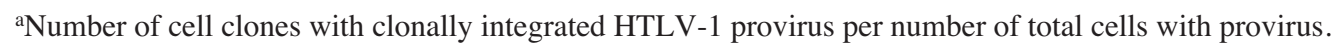

per $10^{5}$ cells in the spleen and 640 per $10^{5}$ cells in the tumors. The number of cells belonging to clones $7 \mathrm{C} 1,7 \mathrm{C} 2,7 \mathrm{C} 3,7 \mathrm{C} 4$ and $7 \mathrm{C} 5$ was estimated to be $80,10,10,10$ and 20 per $10^{5}$ cells in the spleen and $160,160,320,20$ and 20 per $10^{5}$ cells in the tumors, respectively (Table III). These quantitative analyses suggested that those cells proliferating mono- or oligoclonally with integrated HTLV-1 provirus did not constitute the major cell population of the tumors. Namely those tumor cells might not be composed of HTLV-1-infected cells.

\section{Discussion}

The accumulated data support the hypothesis that increased HTLV-1 proviral load and clonal expansion of HTLV-1infected cells are associated with leukemogenesis in HTLV-1 carriers. However, the proviral load and clonal expansion of HTLV-1-infected cells in carriers was not directly evaluated during development to ATL.

The clonal expansion of HTLV-1-infected T-cells is considered necessary to maintain infection. However, the process by which the clonality of HTLV-1-infected T-cells is established is not well understood. We were therefore interested in determining whether the selective maintenance of certain cell clones in carriers contributes to the initiation of leukemogenesis. However, it is difficult to identify and follow the clonal proliferation of infected cells in human reservoir organs. To analyze the process of clonal growth in the early phase of HTLV-1 infection, we utilized our mouse model system in which newborn mice were infected with MT-2 cells, an HTLV-1-infected human T-cell line $(8,9)$. We demonstrated MT-2 cell clearance by 2 weeks post-infection and that clonally expanding HTLV-1-infected murine cells were devoid of contaminating MT-2 cell populations (data not shown). Thus, the provirus detected in the spleens of mice at one month post-infection was from infected murine cells and not from human MT-2 cells. Furthermore, the sequence flanking the integration site in each of the cell clones matched mouse, but not human, genomic sequence.

Interestingly, in infected mice harboring tumors, the number of HTLV-1-infected cells belonging to the same clone was higher in the tumor than in the spleen (Table III). Although the proliferating cell clones containing provirus did not comprise the majority of the cell populations in the tumors (Table III), it should be stressed that the number of HTLV-1-infected cells belonging to the same cell clone was also higher in the tumors than in the spleen, which is the reservoir of HTLV-1 during chronic HTLV-1 infection. However, the relationship between the number of cells belonging to each cell clone and tumor formation remains unclear.

It has been established that HTLV-1-infected cells produce various cytokines that stimulate cell growth, potentially creating a suitable microenvironment for spontaneous tumor formation. Boschi-Pinto et al reported that the incidence of malignant tumors is high among HTLV-1 carriers (19). It is possible that, in addition to the reservoir organs such as spleen and lymphoid organs, spontaneous tumors might also provide a suitable microenvironment for proliferation of infected cell clones (20-22). The above two possibilities are not mutually exclusive. The effect of HTLV-1 infection on formation of malignancies other than leukemias/lymphomas may be clarified using this animal model by characterizing the proliferation of T-cell populations that produce cytokines in various organs in vivo.

\section{Acknowledgments}

We thank Dr Hiroo Hoshino for kindly providing MT-2 and ATL-1K cells. This work was supported in part by a Grantin-Aid for cancer research from the Ministry of Education, Culture, Sports, Science and Technology of Japan. 


\section{References}

1. Uchiyama T, Yodoi J, Sagawa K, Takatsuki K and Uchino H: Adult T-cell leukemia: clinical and hematologic features of 16 cases. Blood 50: 481-492, 1977.

2. Franchini G: Molecular mechanism of human T-cell leukemia/ lymphotropic virus type 1 infection. Blood 86: 3619-3639, 1995.

3. Yamaguchi K, Seiki M, Yoshida M, Nishimura H, Kawano F and Takatsuki K: The detection of human T-cell leukemia virus provirus DNA and its application for classification and diagnosis of T-cell malignancy. Blood 63: 1235-1240, 1984.

4. Yoshida M, Seiki M, Yamaguchi K and Takatsuki K: Monoclonal integration of human T-cell leukemia provirus in all primary tumors of adult T-cell leukemia suggests causative role of human T-cell leukemia virus in the disease. Proc Natl Acad Sci USA 81: 2534-2537, 1984.

5. Maeda Y, Furukawa M, Takehara Y, Yoshimura K, Miyamoto K, Matsuura T, Morishita Y, Tajima K, Okochi K and Hinuma Y: Prevalence of possible adult T-cell leukemia virus carriers among volunteer blood donors in Japan: a nation wide study. Int J Cancer 33: 717-720, 1984.

6. Fialkow PJ: Clonal origin of human tumors. Annu Rev Med 30: 135-143, 1979.

7. Fang J, Kushida S, Feng R, Tanaka M, Kikukawa H, Kawamura T, Uchida K and Miwa M: Integration of HTLV-1 provirus into mouse transforming growth factor- $\alpha$ gene. Biochem Biophys Res Commun 233: 792-795, 1997.

8. Fang J, Kushida S, Feng R, Tanaka M, Kawamura T, Abe H, Maeda N, Onobori M, Hori M, Uchida K and Miwa M: Transmission of human T-cell leukemia virus type 1 to mice. J Virol 72: 3952-3957, 1998.

9. Tanaka M, Sun B, Fang J, Nitta T, Yoshida T, Kohtoh S, Kikukawa H, Hanai S, Uchida K and Miwa M: Human T-cell leukemia virus type 1 (HTLV-1) infection of mice: proliferation of cell clones with integrated HTLV-1 provirus in lymphoid organs. J Virol 75: 4420-4423, 2001.

10. Nitta T, Tanaka M, Sun B, Hanai S and Miwa M: The genetic background as a determinant of human T-cell leukemia virus type 1 proviral load. Biochem Biophys Res Commun 309: 161-165, 2003.

11. Yamato K, Taguchi H, Yoshimoto S, Fujishita M, Yamashita M, Ohtsuki $\mathrm{Y}$, Hoshino $\mathrm{H}$ and Miyoshi I: Inactivation of lymphocyte-transforming activity of human T-cell leukemia virus type 1 by heat. Jpn J Cancer Res 77: 13-15, 1986.
12. Hoshino H, Esumi H, Miwa M, Shimoyama M, Minato K, Tobinai K, Hirose M, Watanabe S, Inada N, Kinoshita K, Kamihira S, Ichimaru $M$ and Sugimura T: Establishment and characterization of 10 cell lines derived from patients with adult T-cell leukemia. Proc Natl Acad Sci USA 80: 6061-6065, 1983.

13. Coutinho A: Genetic control of B-cell response: ii. identification of the spleen B-cell defect in $\mathrm{C} 3 \mathrm{H} / \mathrm{HeJ}$ mice. Scand J Immunol 5: 129-140, 1976.

14. Cavrois M, Wain-Hobson S and Wattel E: Stochastic events in the amplification of HTLV-1 integration sites by linker-mediated PCR. Res Virol 146: 179-184, 1995.

15. Kone J, Arroyo J, Savinelli T, Lin S, Boyd K, Wu Y, Nimmakayalu M, Copeland NG, Jenkins NA, Qumsiyeh M, $\mathrm{Hu}$ P, Prescott A, Wu H, Yang L, Roe B and Perkins AS: FMuLV acceleration of myelomonocytic tumorigenesis in SV40 large $\mathrm{T}$ antigen transgenic mice is accompanied by retroviral insertion at Fli1 and a novel locus, Fim4. Leukemia 16: 1827$1834,2002$.

16. Jin G, Tsuruyama T, Yamada $\mathrm{Y}$ and Hiai H: Svi3: A provirus common integration site in c-myc in SL/Kh pre-B lymphomas. Cancer Sci 94: 791-795, 2003.

17. Hanai S, Nitta T, Shoda, Tanaka M, Iso N, Mizoguchi I, Yashiki S, Sonoda S, Hasegawa Y, Nagasawa T and Miwa M: Integration of human T-cell leukemia virus type 1 in genes of leukemia cells of patients with adult T-cell leukemia. Cancer Sci 95: 306-310, 2004.

18. Ozawa T, Itoyama T, Sadamori N, Yamada Y, Hata T, Tomonaga $\mathrm{M}$ and Isobe $\mathrm{M}$ : Rapid isolation of viral integration site reveals frequent integration of HTLV-1 into expressed loci. J Hum Genet 49: 154-165, 2004.

19. Boschi-Pinto C, Stuver S, Okayama A, Trichopoulos D, Orav EJ, Tsubouchi $\mathrm{H}$ and Mueller N: A follow-up study of morbidity and mortality associated with hepatitis $\mathrm{C}$ virus infection and its interaction with human T lymphotropic virus type I in Miyazaki. Jpn J Infect Dis 181: 35-41, 2000.

20. Watanabe T: HTLV-1-associated diseases. Int J Hematol 66: 257-278, 1997.

21. Matsuoka M: Human T-cell leukemia virus type I and adult T-cell leukemia. Oncogene 22: 5131-5140, 2003.

22. Yasunaga $\mathbf{J}$ and Matsuoka M: Leukemogenesis of adult T-cell leukemia. Int J Hematol 78: 312-320, 2003. 